\title{
A PRELIMINARY STUDY ON THE GROWTH AND FOOD OF STOLEPHORUS SPP. FROM THE JAKARTA BAY ${ }^{1}$ )
}

by

BURHANUdDin, SUlarto MARTOSEWOJO and MaLiKuSWORO HutOMO ${ }^{2}$ )

(Manuscript received 25 June 1973)

\begin{abstract}
The length compositions of Stolephorus heterolobus, Stolephorus insularis and Stolephorus pseudoheterolobus were observed. S. heterolobus ranged from 25 to $71 \mathrm{~mm}$., S. insularis from 27 to $75 \mathrm{~mm}$ and S. pseudoheterolobus from 27 to $67 \mathrm{~mm}$ standard length.

The ages of these three species were estimated. The asymptotic length of S. heterolobus was $97 \mathrm{~mm}$ attained at the age of 26 months, S. insularis $86 \mathrm{~mm}$ at 26 months and $S$. pseudohetorolobus $88 \mathrm{~mm}$ at 20 months.

The highest growth rate of $S$. heterolobus was at the size group $30-80 \mathrm{~mm}$ standard length, that of $S$. insularis was at 30-50 $\mathrm{mm}$, and that of $S$. insularis was observed to be the lowest.

The stomach contents of $S$. heterolobus and S. pseudoheterolobus were studied tand were found that the food of these two species was more or less the same. They fed mainly on zooplankton consisting of copepods and other crustaceans.
\end{abstract}

\section{IKHTISAR}

Dipelajari komposisi panjang ikan teri, Stolephorus heterolobus, Stolephorus insularis dan Stolephorus pseudoheterolobus, di Teluk Jakarta. Panjang S; heterolobus berkisar antara 25-71 mm, S. insularis antara $27-75 \mathrm{~mm}$ dan S. Pseudoheterolobus antara 27 - $67 \mathrm{~mm}$.

Umur ketiga jenis ikan teri tersebut diperkirakan. Panjang maksimum S. heterolobus, $97 \mathrm{~mm}$, dicapai pada umur 26 bulan; 5. insularis, $86 \mathrm{~mm}, 26$ bulan dan S. pseudoheterolobus, $88 \mathrm{~mm}, 20$ bulan.

Laju tumbuh tercepat $S$. Heterolobus terdapat pada ukuran $30-80 \mathrm{~mm}, S$. insularis pada ukuran $30-50 \mathrm{~mm}$ dan $S$, pseudoheterolobus pada ukuran $30-75 \mathrm{~mm}$. Jadi laju tumbuh $S$. insularis paling lambat.

Kandungan isi perut $S$. heterolobus dan S. pseudoheterolobus diperiksa dan diketahui bahwa makanan kedua jenis ikan teri tersebut kurang lebih sama. Makanan utamanya ialah plankton hewani yang terutama terdiri atas copepoda dan jenis Crustacea lain.

\section{INTRODUCTION}

Marine fish which is easily available from Jakarta Bay in large amount would be of a great benefit to the population of Jakarta. One of the fish genera, Stolephorus or known locally as ikan teri, is one of the important commercial fish in this area. In 1970 the catches of Stolephorus in Jakarta reached 7847 metric tons. This comprised $15.82 \%$ of the bay total yields.

This fish is usually caught by means of bagan, sero and payang. The specimens studied were caught by bagan. A bagan is constructed of four bamboo poles planted vertically in the bottom of the sea. At about

1) Contribution of the Lembaga Oseanologi Nasional, Lembaga Ilmu Pengetahuan Indonesia.

${ }^{2}$ ) Lembaga Oseanologi Nasional; Jakarta, Indonesia. 
5 meters above the sea-level a square platform is built. Underneath this platform a lighted pressure lamp is hung to attract fish. A net which can be raised or lowered to catch the attracted fish is set under the platform. Bagan is operated at night only. During full moon or bright nights bagan is suspended.

Five species of Stolephorus were caught during the observation Period, but only three species, Stolephorus heterolobus RTJPPELL, Stolephorus insularis HARDENBERG and Stolephorus pseudoheterolobus HARDENBERG were studied. The other two, Stolephorus indicus (VAN HASSELT) and Stolephorus zollingeri (BLEEKER) were disregarded due to the insufficient data.

This paper deals with the study of the length compositions, the growth and the food of these three species of ikan teri from Jakarta Bay.

\section{MATERIALS AND METHODS}

The samplings were carried out at irregular intervals from May 1970 to December 1971. All samples were collected at random from Bagan I and Bagan II in the Jakarta Bay (Fig. 1), preserved in $10 \%$ formaline immediately after hauling, brought to the laboratory the next morning and treated in different manners according to the purpose of study.

The standard length was measured in $\mathrm{mm}$ with $2 \mathrm{~mm}$ interval. For example, fish of $20-22 \mathrm{~mm}$ length was read as $21 \mathrm{~mm}$. Thus only odd numbers were presented for all size groups. The data obtained were calculated in percentage and every sample was plotted as a frequency polygon. The abscissa of the polygon indicated the length of the fishl and the ordinate indicated the percentage of frequency. The mode was considered as the average length of one fish group. The sample notationts were given to each polygon in alphabetic order A, B, C, etc. A suffix was added to each notation to denote the mode in a sample having more than one mode, viz. Al, A2, Bl, B2, Cl, C2, etc.

Some modes could not be connected as a mode-chain to show the growth rate. Other modes were linked together to form mode-chains which conformed to the general growth curve of fish and each mode-chain was taken to represent one brood of the growing fish. The hypothetical growth was calculated for each brood by taking the difference in length between two adjacent modes in the mode-chain, and dividing them by the time interval in days.

By following the method of GuLlaND and HolT (1959), the catabolic growth rate coefficient $(\mathrm{K})$ and the asymptotic length ( $\mathrm{L} \sim)$ of the VON BERTALANFFY growth equation were calculated. The equation of GuLLAND and Holt is:

$$
\frac{\left(1_{2}-1_{1}\right)}{\left(t_{2}-t_{1}\right)}=K\left(L-\frac{1_{1}+1_{2}}{2}\right)
$$

$1_{1}$.represents the length of the fish when released

$1_{2}$ represents the length of the fish on recapture

$\left(t_{2}-t_{1}\right)$ represents the time elapsed between release and recapture.ture. 
Then THAM's (1966 b) calculation method was used for interpreting the age of fish studied at Jakarta Bay.

In the case of Stolephorus heterolobus, 24 samples were collected during the period May 1970 to October 1971. The samples for August 1970, January, March and August 1971 were not available. A total of 9124 specimens of this fish were measured for the study.

Stolephorus insularis was represented by 16 samples collected during the period April 1970 to December 1971. Some gaps were encountered in June, August and October 1970, and January, February, March, April, June and August 1971. A total of 2634 specimens of this fish were measured for the study.

Fifteen samples of Stolephorus pseudoheterolobus were collected during the period March 1970 to November 1971. The specimens of this fish measured for this study were 7254 .

The stomach contents of these fish were observed under a Leitz binocular microscope. Every organism found in the stomachs was identified to the lowest possible taxa. In analyzing food habits, the number method suggested by PILLAY (1952) for plankton feeder was followed. This examination was carried out from May 1970 to July 1971, involving 41 specimens of $S$. pseudoheterolobus and 81 specimens of $S$. heterolobus.

\section{RESULTS}

\section{Stolephorus heterolobus}

\section{a. Length frequency distribution}

The smallest specimen collected was $25 \mathrm{~mm}$ taken on 16 May 1971, and the biggest was $71 \mathrm{~mm}$ dated 19 and 29 September, 1971. The fish at less than $25 \mathrm{~mm}$ long could not be identified. The graphs were mostly polymodal except some samples taken on 6 June, 23 October, 19 December 1970 (Fig. 2) and 24 February, 30 May and 19 September 1971 (Fig. 3) which showed one mode. These modes ranged from $30 \mathrm{~mm}$ to $70 \mathrm{~mm}$.

\section{b. Growth}

Modes which could be connected as mode-chains representing the instantaneous growth rate (Fig. 4) were selected from the modes plotted. The instantaneous growth rate, i.e. the growth rate between adjacent modes in a mode-chain $\frac{1_{2}-1_{1}}{t_{2}-t_{1}}$ and the mean length of those adjacent modes $\left(1_{1}+1_{2}\right)$ were calculated and given in Table I. The regression of the instantaneous growth rate $(y)$ on the mean length $(x)$ was calculated and represented by equation:

$$
\mathrm{y}=0.0066 \mathrm{x}+0.6381
$$

From this, $\mathrm{K}=0.0066$. By following equation (1) the value of $\mathrm{L} \approx$ was calculated to be $97 \mathrm{~mm}$. Subsequently, one chain which contained the smallest mode was selected. A hypothetical age of 'a' days was given to this mode. The adjacent related mode became ' $a$ ' + ' $x$ ' days where ' $x$ ' 
was calculated from the time interval between samples. The unkown 'a' could be found out, if the growth rate of the newly hatched fish was known. The growth observed by DELSMAN (1931) for Stolephorus heterolobus after hatching was $0.88 \mathrm{~mm} /$ day at the length of $1.90 \mathrm{~mm}$. The instantaneous growth rate of the smallest mode $(33 \mathrm{~mm})$ to $37 \mathrm{~mm}$ of the next mode-chain was calculated by substituting the value of $\mathrm{K}$ and $\mathrm{L}$-n into the equation (1).

$$
\begin{aligned}
\frac{\left(1_{2}+1_{1}\right)}{t_{2}-t_{1}} & =0.0066\left(97-\frac{33+37}{2}\right) \\
& =0.0066(97-35) \\
& =0.41 \mathrm{~mm} / \text { day }
\end{aligned}
$$

The growth of this species up to the length of $33 \mathrm{~mm}$ was something between $0.88 \mathrm{~mm} /$ day and $0.41 \mathrm{~mm} /$ day, or on the average was about $0.65 \mathrm{~mm} /$ day. It is known that the longer the fish, the slower the growth rate, hence, this growth rate assumed was too fast when it approached the length of $33 \mathrm{~mm}$. Therefore, the assumption should be halfway between $0.65 \mathrm{~mm} /$ day and $0.41 \mathrm{~mm} /$ day, i.e. $0.53 \mathrm{~mm} /$ day. The time required for this species to grow up to $33 \mathrm{~mm}$ was equal to $\frac{33-1.90}{0.53}=59$ days.

The value of $t-t_{0}$ for each value of $l_{t}$ (Table II, column 2) was calculated from the equation:

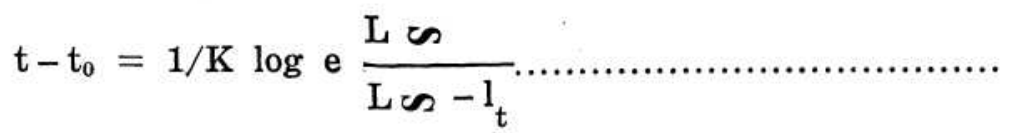

$t=$ the time needed for the growth of the newly hatched fish to a certain length $l_{t}$

$t_{0}=$ the time needed for the development of the egg, from the time of ovulation to the hatching period.

A line of best fit, which was obtained from the values of t-a (Table II, column 3) plotted against the corresponding values of $t-t_{0}$ (Table II, column 4), was calculated by the method of least square. This line intercepted the ordinate at $\left(t_{0}+a\right)=80$ days. Since $t_{0}$ was the period of incubation before the hatching time, and the age of the newly hatched fish was considered as zero days, therefore the value of $\mathrm{t}_{0}$ was negative, equal to - 21 days.

From this result the hypothetical age of each individual from the standard length of $30 \mathrm{~mm}$ to the standard length of $70 \mathrm{~mm}$ at intervals of $10 \mathrm{~mm}$, from $70 \mathrm{~mm}$ to $90 \mathrm{~mm}$ at intervals of $5 \mathrm{~mm}$, from $90 \mathrm{~mm}$ to $94 \mathrm{~mm}$ at intervals of $2 \mathrm{~mm}$, and the rest up to the length of $96.50 \mathrm{~mm}$ at intervals of $1 \mathrm{~mm}$ were calculated (Fig. 12 and Table VII). 


\section{c. Food}

The food of this species consisted mainly of zooplankton. However, phytoplankton such as Coscinodiscus and dinoflagellates, were occasionally observed. The predominant zooplankton organisms were indicated by fragments of crustaceans and copepods (Figs. 5 and 6, Table VIII). Some other organisms were occasionally found in a relatively high percentage. For example, the sample of May 1970 showed that eggs and fish scales accounted for $11.64 \%$ and unidentified forms for $13.83 \%$; of June 1970 indicated that other crustaceans comprised $19.36 \%$ and of October 1970 molluscs accounted for $18.36 \%$.

Fragments of crustaceans were increasing from 33.02\% in May 1970 to $88.54 \%$ in December 1970 (Fig. 5). On the contrary, the monthly variations of copepods were decreasing from 35.52\% in May 1970 to $4.16 \%$ in December 1970. The phytoplankton were found only in May, September and October 1970.

Observations made in June and July 1971, with fragments of crustaceans and copepods still predominating the percentage of food items, showed that the diet of this species in 1971 was similar to that in 1970.

\section{Stolephorus insularis}

\section{a. Length frequency distribution}

The shortest specimen was $27 \mathrm{~mm}$, collected on 29 September 1971 and the longest was $75 \mathrm{~mm}$, dated 13 Desember 1971. The graphs were mainly polymodal. The unimodal polygons were found on 29 April, 19 September and 19 December 1970, and on 12 September, 26 October, 27 November and 13 December 1971 (Fig. 6). Those modes ranged between $31 \mathrm{~mm}$ and $70 \mathrm{~mm}$.

\section{b. Growth}

The instantaneous growth rates and the mean length of these adjacent modes were calculated (Table III). It was represented by the equation

$$
\mathrm{y}=-0.0044 \mathrm{x}+0.3779
$$

From this, $K=0.0044$ and the value of $\mathrm{L} n$ was equal to $86 \mathrm{~mm}$. The growth observed by DELSMAN (1931) for this fish immediately after hatching was from $0.46 \mathrm{~mm}$ to the length of $2.30 \mathrm{~mm}$ within 18 hours. Assuming that the size did not increase or slightly increased, then the growth rate from the time of hatching up to an age of 24 hours was $0.46 \mathrm{~mm} /$ day. By following the same method for Stolephorus heterolobus, the instantaneous growth rate of the smallest mode $(31 \mathrm{~mm})$ was found to be $0.22 \mathrm{~mm} /$ day. The increase of growth assumed was too rapid when it approached the length of $31 \mathrm{~mm}$. Therefore, the assumption should be halfway between $0.46 \mathrm{~mm} /$ day and $0.22 \mathrm{~mm} /$ day i.e. $0.34 \mathrm{~mm} /$ day. The time required for this species to grow up to $31 \mathrm{~mm}$ ('a') was equal to $\frac{31-2.30}{0.34}=84$ days.

The value of $t-t_{0}$ for each value of $l_{t}$ was calculated by applying equation (3) (Table IV, column 4). A line of best fit, which was obtained from the values of $t-a$ plotted against the corresponding values of $t-t_{0}$, 
was calculated by method of least square (Fig. 8). The line intercepted the ordinate at $\left(t_{0}-a\right)=87$ days, therefore the value of $t_{0}=-3$ days.

From that result, the hypothetical age of this fish was calculated (Fig. 12, Table VII).

\section{Stolephorus pseudoheterolobus}

\section{a. Length frequency distribution}

The minimum length of fish collected was $27 \mathrm{~mm}$, caught on 6 June and 8 October 1970; the maximum length was $67 \mathrm{~mm}$, caught on 24 August 1971. Most of the graphs were polymodal, but one third of them were unimodal, i.e. those of 20 May, 8 October 1970 and 24 August, 26 October and 24 November 1971 . The modes ranged between $30 \mathrm{~mm}$ and $65 \mathrm{~mm}$ (Fig. 9).

\section{b. Growth}

The instantaneous growth rate and the mean length of those adjacent modes were calculated (Table V). It was represented by the equation $\mathrm{y}=-0.0092 \mathrm{x}+0.8091$. Thus, $\mathrm{K}=0.0092$ and $\mathrm{L} n=88 \mathrm{~mm}$. From DELSMAN's (1931) observation, the growth rate from the time of hatching to an age of 24 hours was $0.90 \mathrm{~mm}$ /day at the length of $1.54 \mathrm{~mm}$. The instantaneous growth rate of this species up to the length of $33 \mathrm{~mm}$ should be something between $0.90 \mathrm{~mm} /$ day and $0.49 \mathrm{~mm} /$ day i.e. 0.70 $\mathrm{mm} /$ day. The increase in growth assumed was too rapid when it approached the length of $33 \mathrm{~mm}$, the assumption should be halfway between $0.70 \mathrm{~mm} /$ day and $0.49 \mathrm{~mm} /$ day i.e. $60 \mathrm{~mm} /$ day. The time required for this species to grow up to $33 \mathrm{~mm}$ ('a') was equal to:

$\frac{33-1.54}{0.60}=52$ days.

The values of $t-t_{0}$ for each value of $l_{t}$ were calculated by applying equation (3) (Table VI, column 4). A line of best fit, which was obtained from the values of $t-a$ (column 3 ) plotted against the corresponding values of $t-t_{0}$, was calculated by method of least square (Fig. 11). The line intercepted the ordinate $\left(t_{0}-a\right)$ at 56 days, so the value of $t_{0}$ was equal to -4 days.

From that result the hypothetical age of this fish was calculated (Fig. 12; Table VII).

\section{c. Food}

The food of this species is more or less similar to that of Stolephorus heterolobus. Fragments of Crustacea and copepods predominated (Fig. 15, Table IX). The phytoplankton were also found in small quantities and consisted of Coscinodiscus and dinoflagellates. 


\section{DISCUSSION}

The fastest growth of Stolephorus heterolobus was at the interval of 30 to $80 \mathrm{~mm}$ (Fig. 12). This value was similar to that of Stolephorus pseudoheterolobus which had fastest growth at the interval of SO to $75 \mathrm{~mm}$. The growth of Stolepohorus insularis was slower than that of the other two species. Its fastest growth was at the interval of 30 to $50 \mathrm{~mm}$.

It is interesting to compare the growth of S. pseudoheterolobus and S. insularis of the Jakarta Bay with that of the Singapore Strait examined by THAM (1966b). It appears that there are several differences which can be seen below.

\section{Stolephorus pseudoheterolobus}

\begin{tabular}{|c|c|}
\hline THAM's examination & Present examination \\
\hline $\mathrm{K}=0.0057$ & $\mathrm{~K}=0.0092$ \\
\hline $\mathrm{L}_{\mathscr{\Omega}}=89 \mathrm{~mm}$ & $\mathrm{~L}_{\mathscr{\Omega}}=88 \mathrm{~mm}$ \\
\hline Calculated age at $\mathrm{L}_{\mathscr{C}}=902$ days & Calculated age at $\mathrm{L}_{\mathscr{\Omega}}=600$ days \\
\hline
\end{tabular}

Stolephorus insularis

\begin{tabular}{cc}
\hline \hline Tham's examination & Present examination \\
\hline $\mathbf{K}=0.0057$ & $\mathrm{~K}=0.0044$ \\
$\mathrm{~L} \boldsymbol{\sim}=99 \mathrm{~mm}$ & $\mathrm{~L} \boldsymbol{\Omega}=86 \mathrm{~mm}$ \\
Calculated age at $\mathrm{L} \boldsymbol{\sim}=899$ days & Calculated age at $\mathrm{L} \boldsymbol{\Omega}=780$ days \\
\hline
\end{tabular}

Although the values of $\mathrm{K}$ of $S$. pseudoheterolobus from both localities showed a marked difference, the values of $L$ in were similar. The difference in values of $\mathrm{K}$ of this species might be due to the habitat. The calculated age at $\mathrm{L} \sim \mathrm{N}$ was 780 days for the species of the Jakarta Bay, 899 days for that of the Singapore Strait. These different results were due to the difference in calculating the growth rate from time of hatching to age of 24 hours.

The asymptotic length of $S$. insularis of the Jakarta Bay was shorter than that of the Singapore Strait and was faster to reach it.

From the observed data of the food of $S$. heterolobus as well as that of $S$. pseudoheterolobus, it was apparent that crustaceans were always found in the greatest percentage. Therefore, it might be concluded that crustaceans were the main food of these species. 


\section{ACKNOWLEDGEMENTS}

The authors are greatly indebted to Mr. SujATnO BiROwo, the Head of the Institute of Marine Research, for his encouragement, and to Mr. KASUAN ROMIMOHTARTO for his guidance and valuable suggestions.

We are thankful to Miss SuSAN REYNOLDS and Mr. DJOKO PRAWOTO PRASENO for the corrections of the English text, Mr. ASIKIN DJAMALI for the treatments of the data, Mr. SoJOTO and Mr. SuTOPO, technical assistants, for their participation in collecting, preserving, and measuring the fish specimens.

\section{REFERENCES}

Delsman, H. C. 1931. Fish eggs and larvae from the Java Sea. 17. The genus Stolephorus. Treubia 13(2): $217-243$.

Gulland, J. A. and S. J. Holt 1959. Estimation of growth parameters for data at unequal time interval. J. du Conseil 25 (1): 47-52.

Pillay, T. V. R. 1952. A critique at the methods of the study of food of fishes. J. Zool. Soc. India 4(2): 186-200.

Тнам, А. K. 1966 a. A preliminary study of the growth rate of Stolephorus pseudoheterolobus HARDENBERG. Mai Agrl. J. 45(3') i25'8 - 266.

-- $1966 \mathrm{~b}$. A contribution to the study of the growth of members of the genus Stolephorus LACEPEDE in Singapore Straits. Proc. Indo-Pacific Fish. Coun. 12 (2): 1 - 25. 


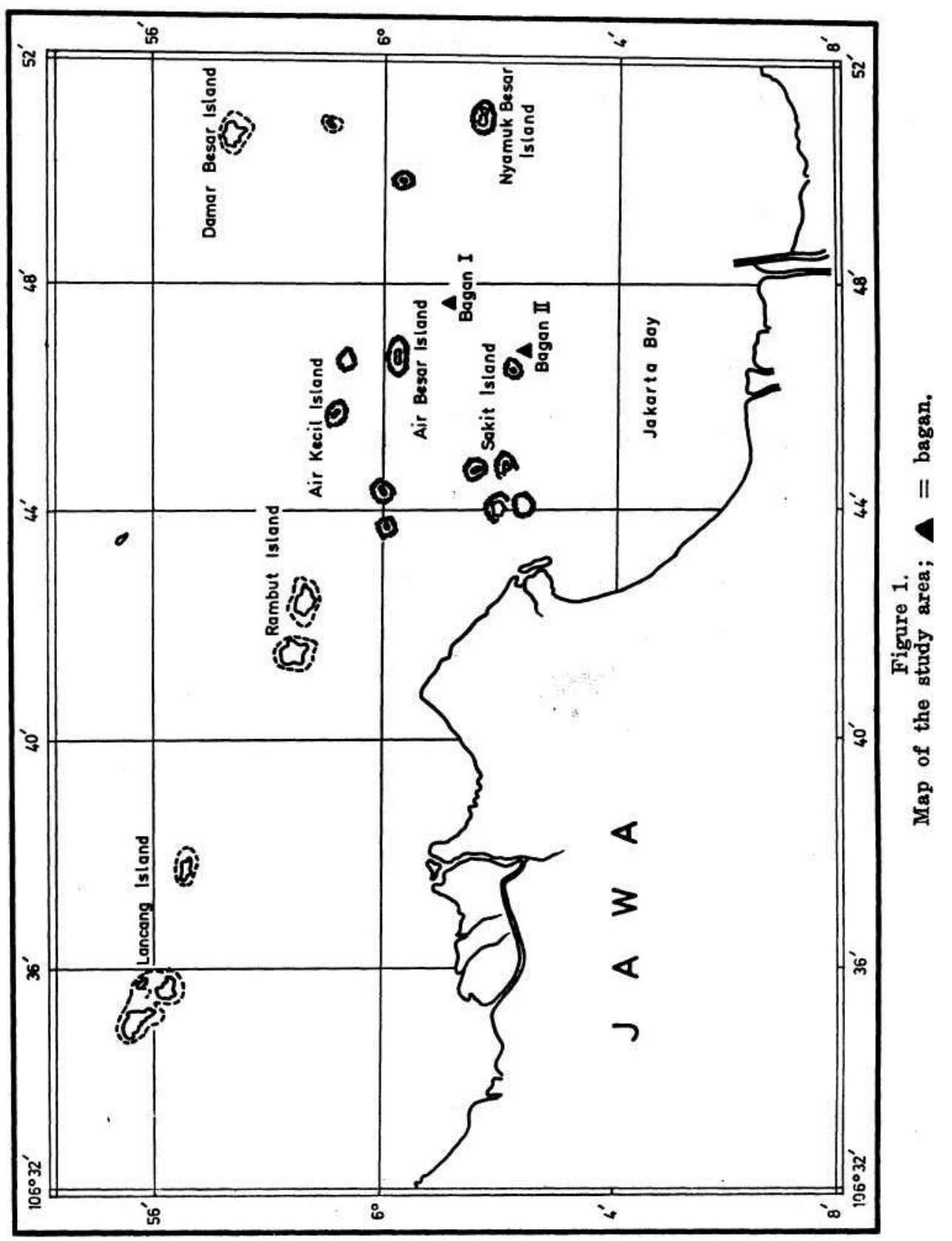




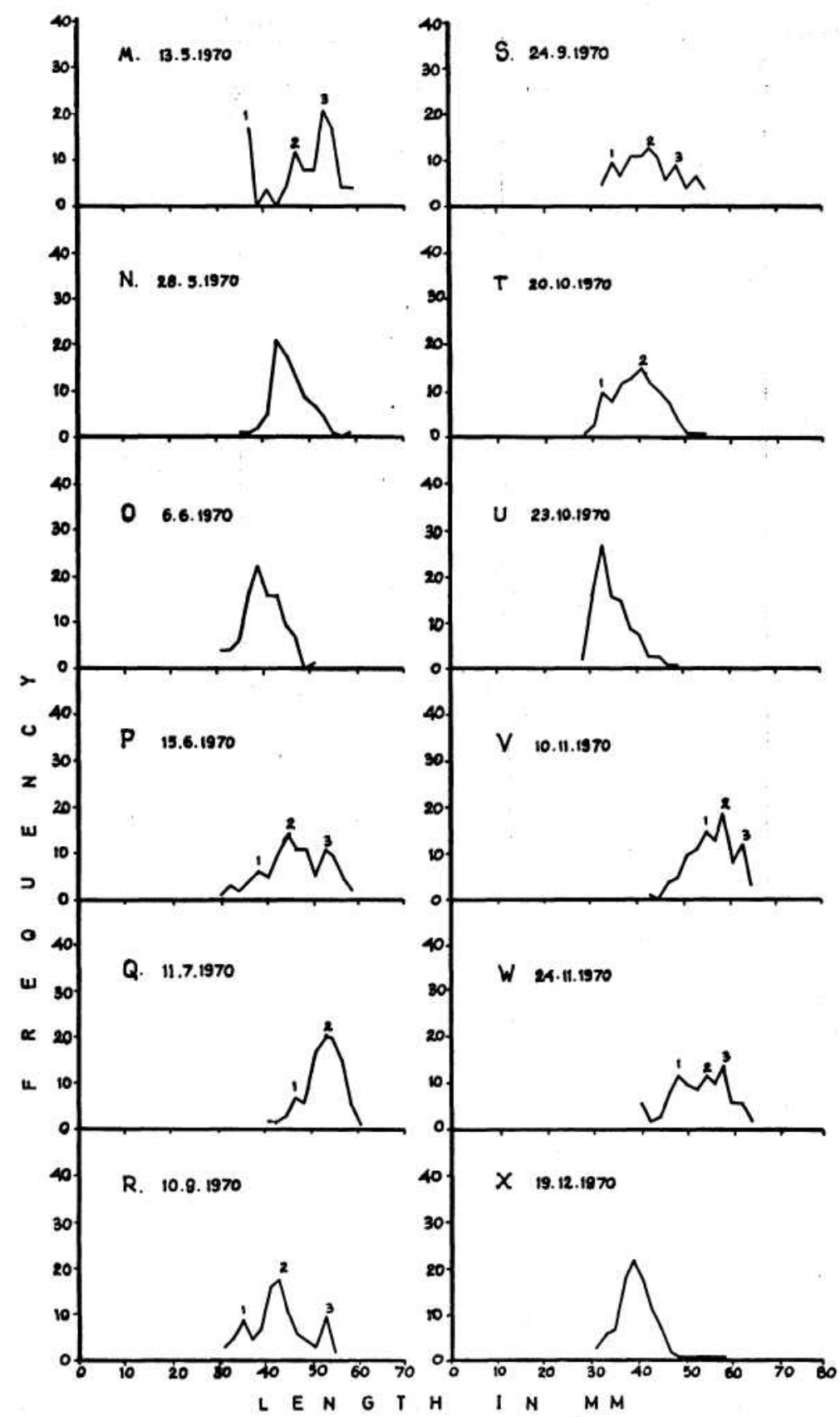

Figure 2.

Length frequency polygon of $S$. heterolobus in 1970. 


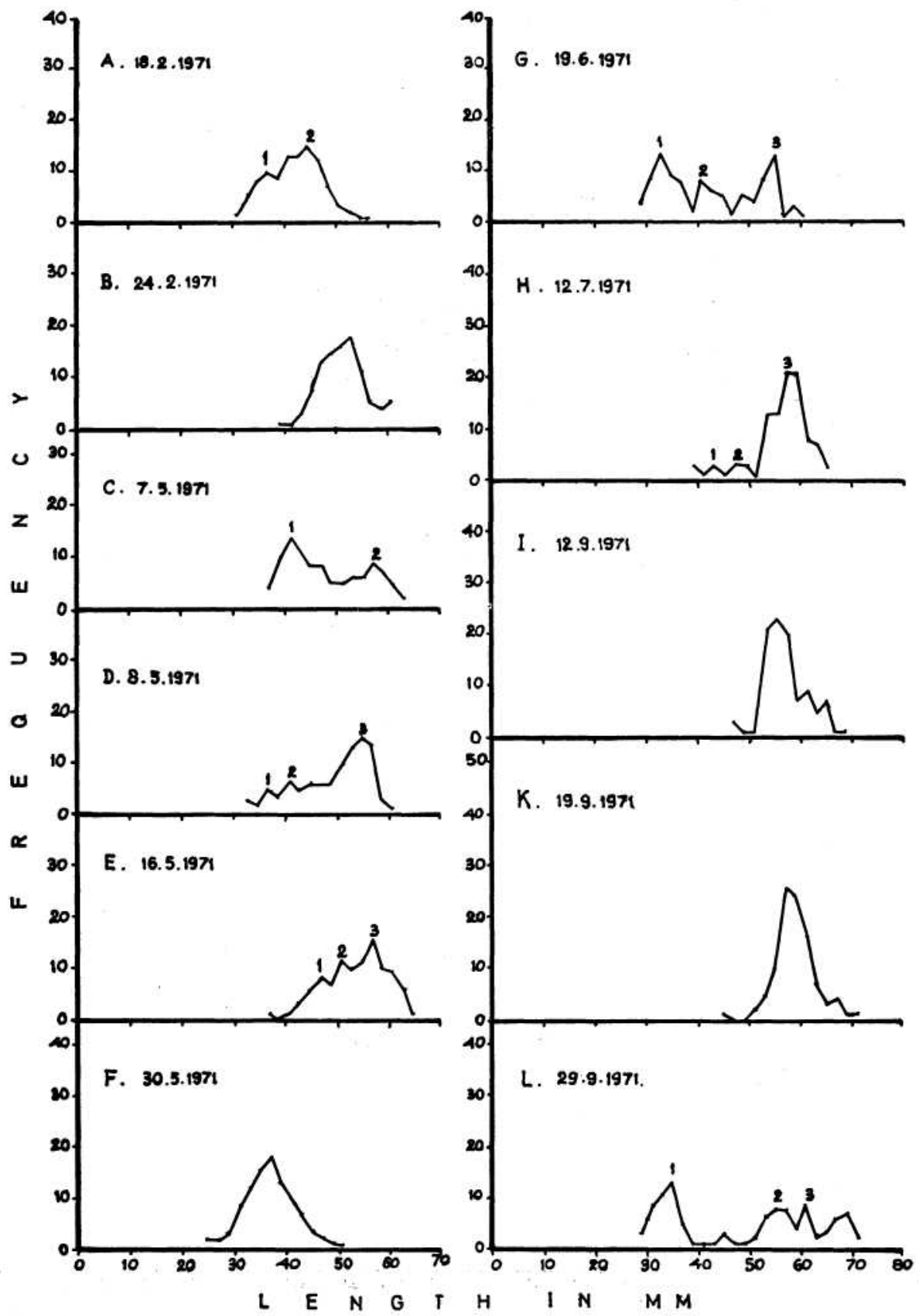

Figure 3.

Length frequency polygon of S. heterolobus in 1971. 

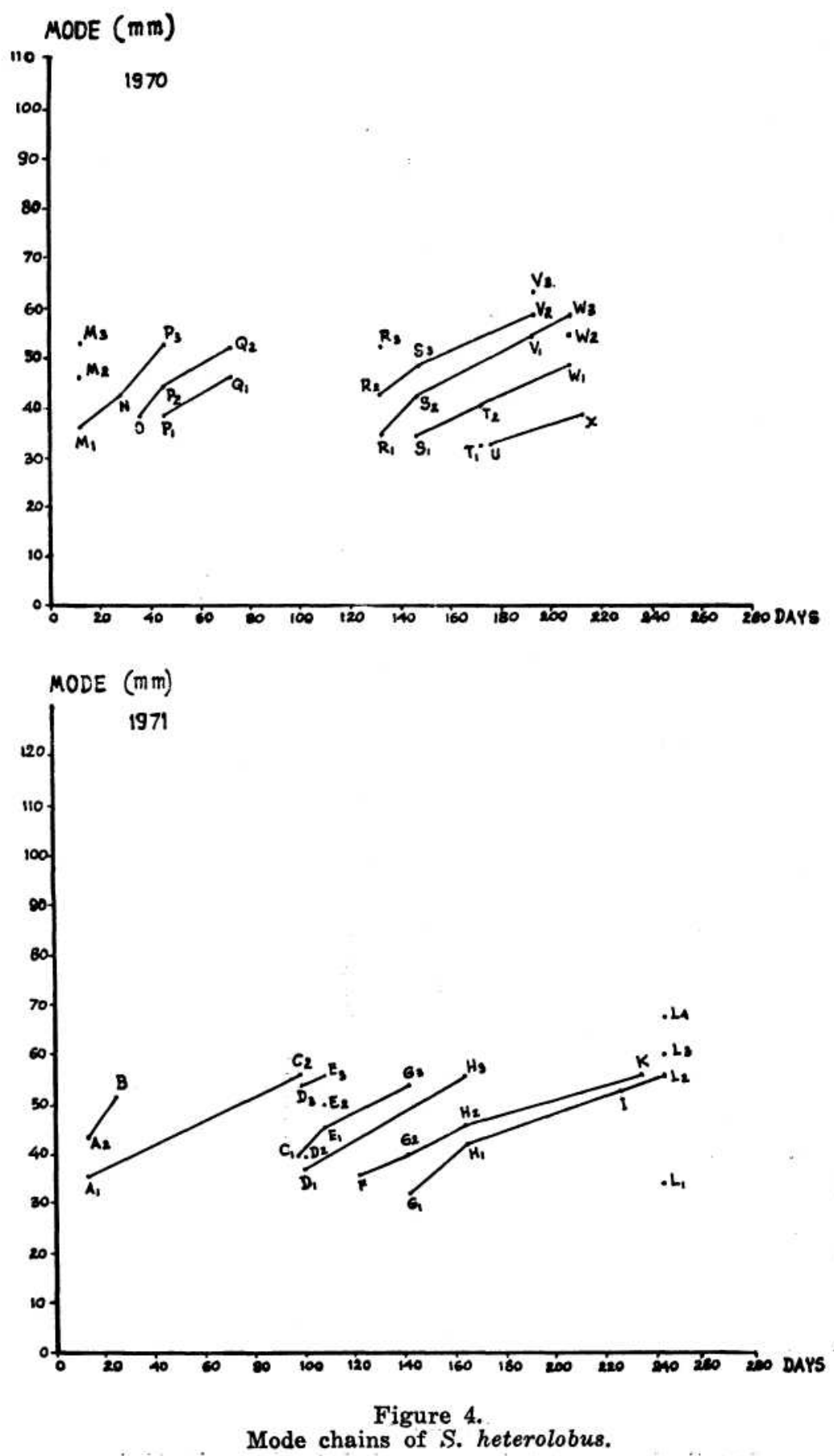


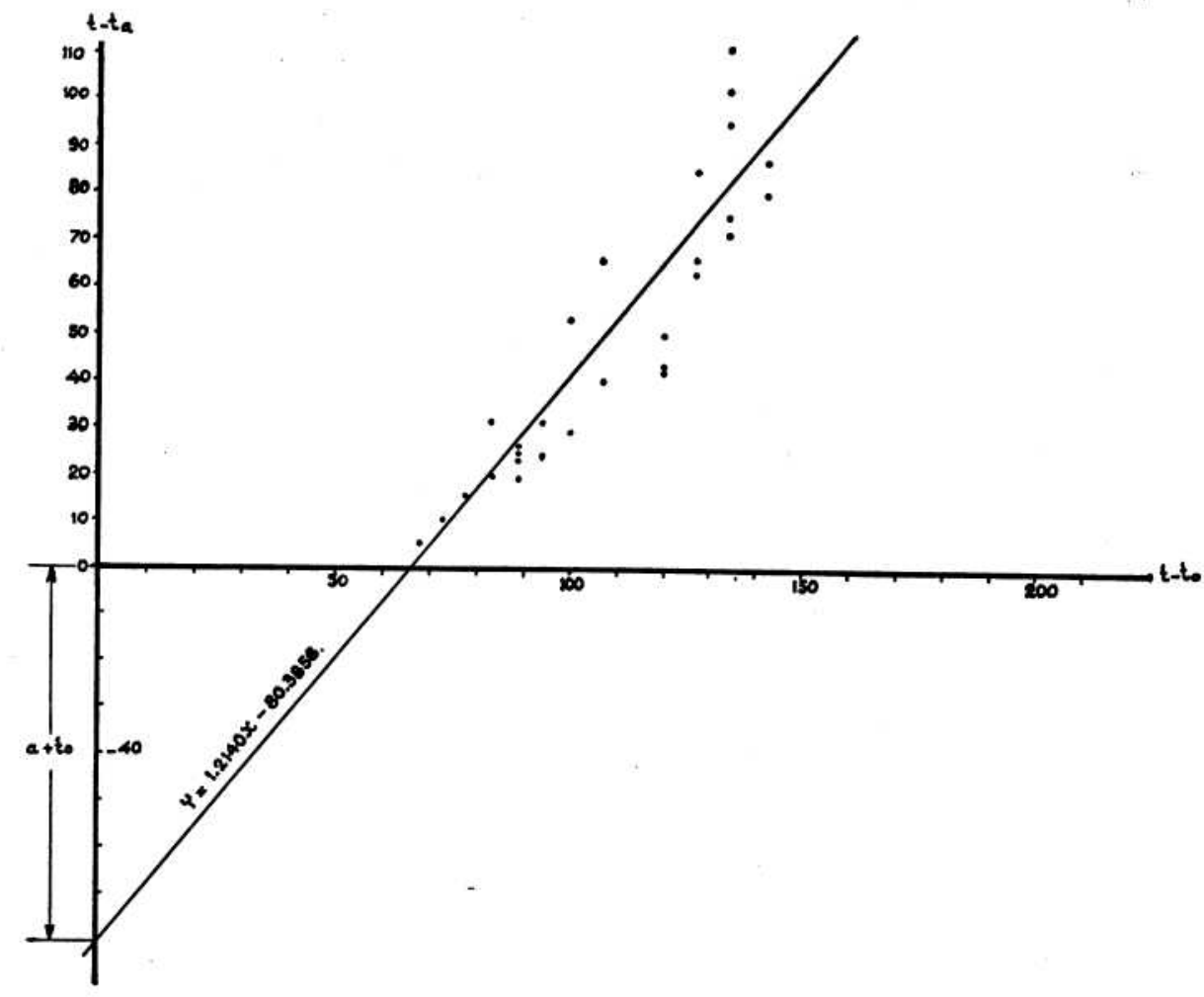

Figure E.

S. heterolobus. Regression of $(t-a)$ on $\left(t-t_{0}\right)$ 


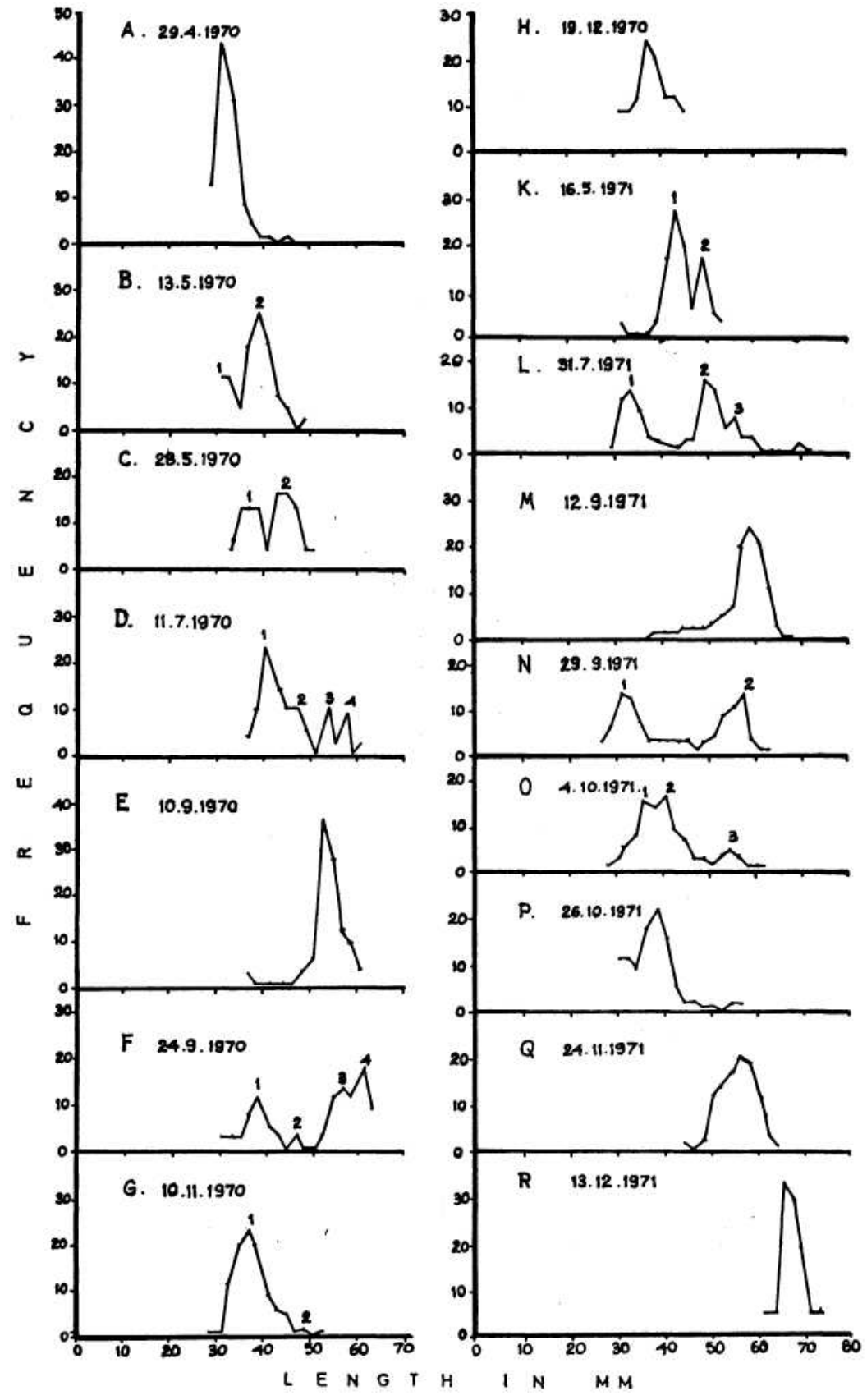

Figure 6.

Length frequency polygon of $S$. insularis in $1970-1971$. 

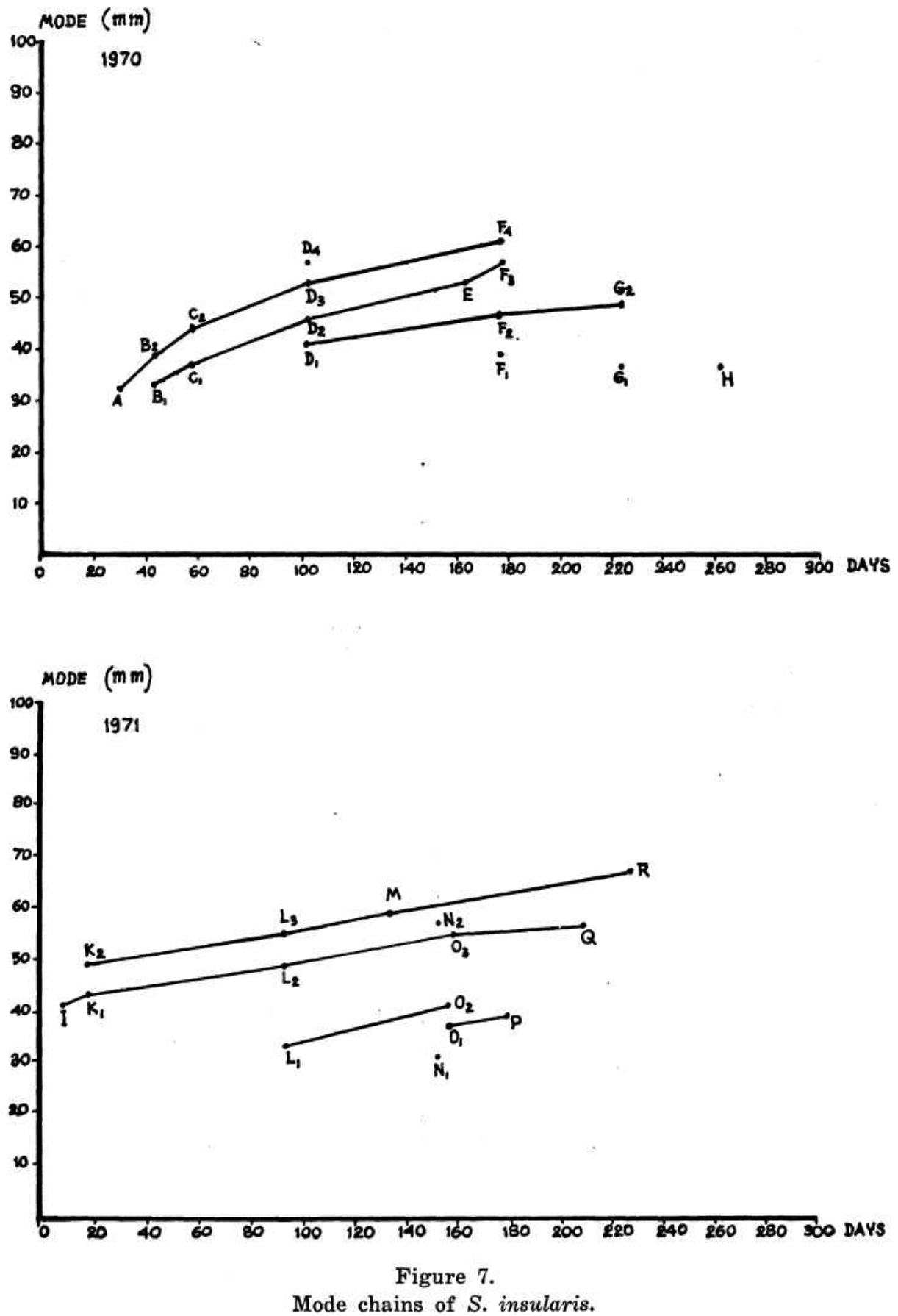


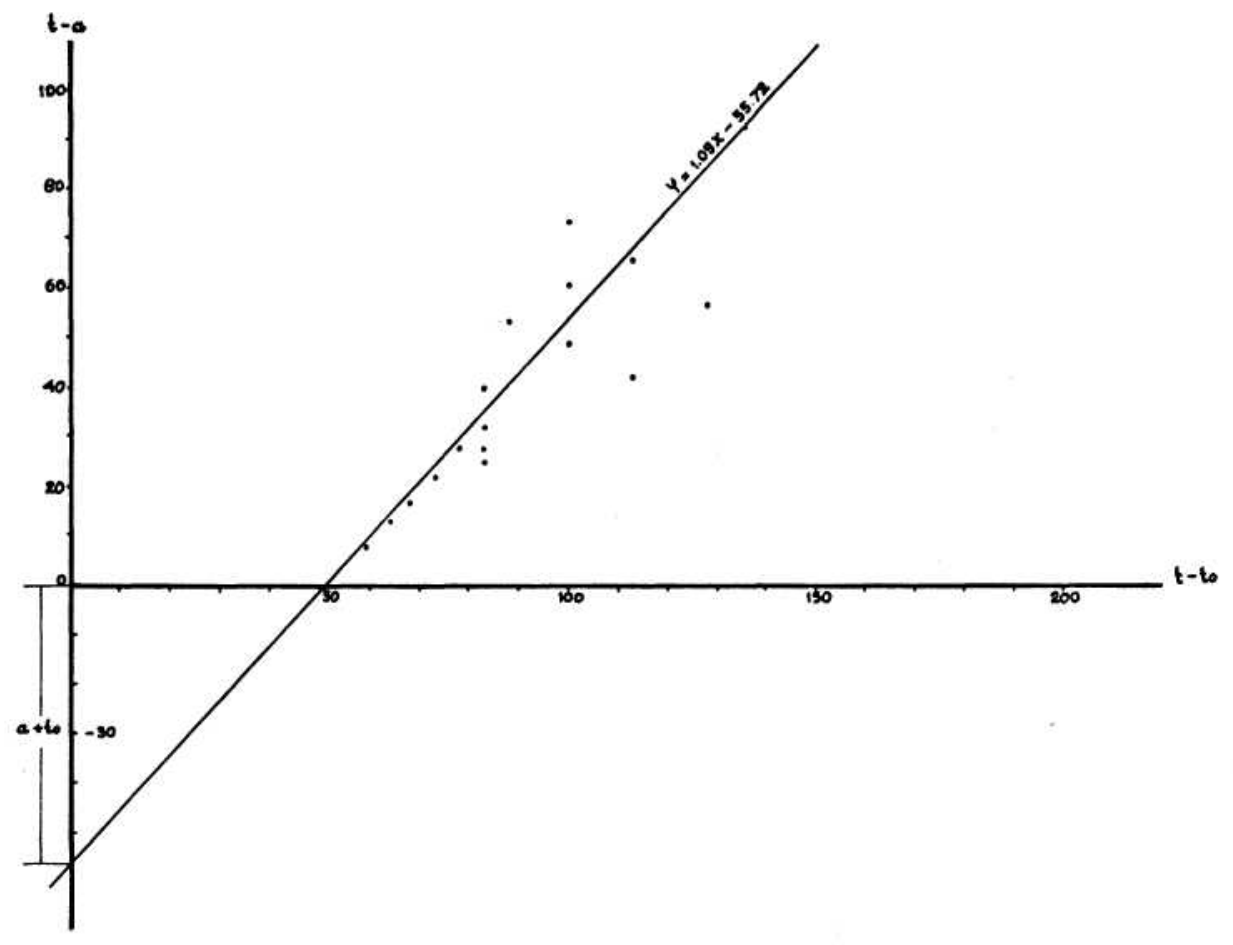

Figure 8.

S. insularis. Regression of $(t-a)$ on $\left(t-t_{0}\right)$. 

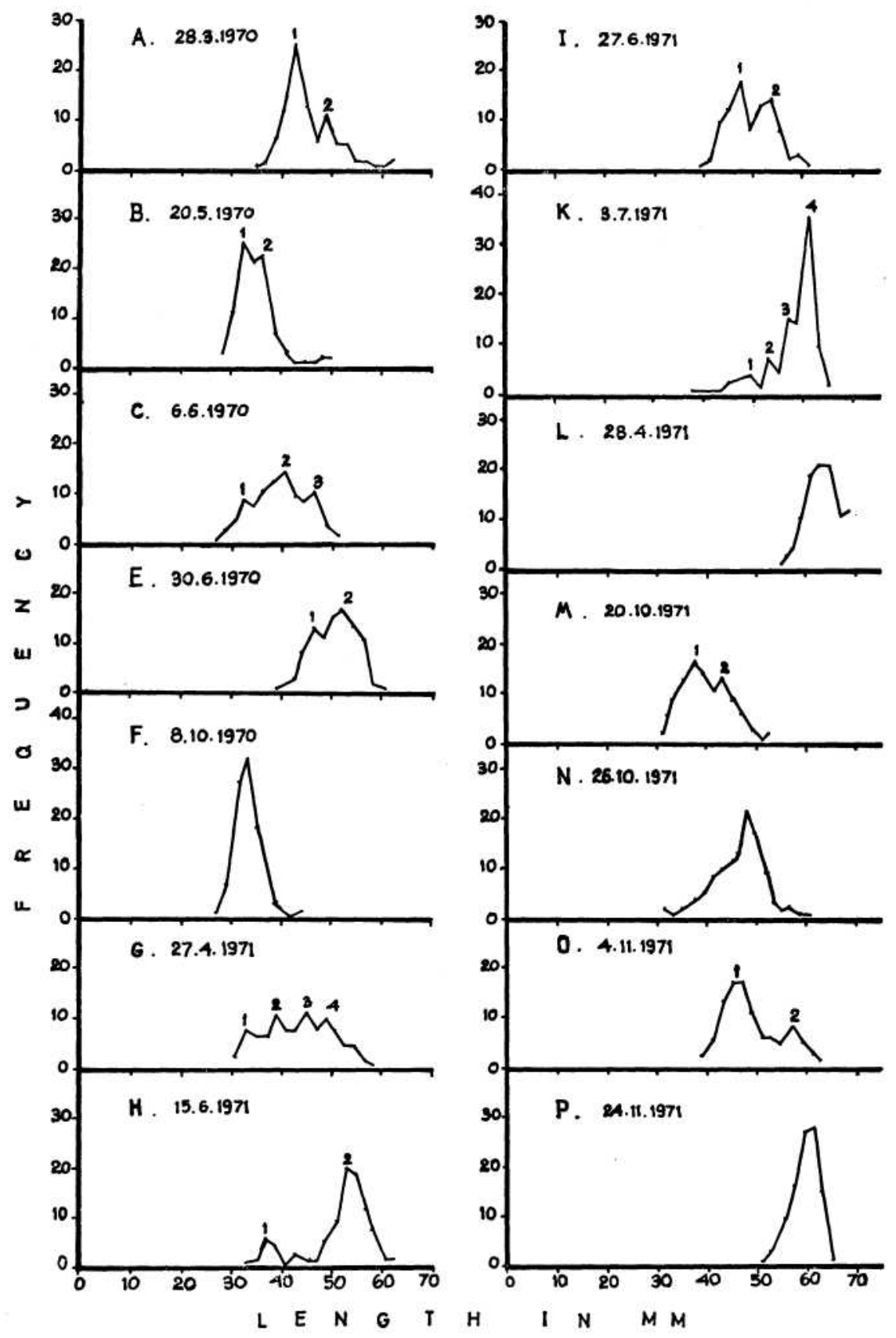

Figure 9.

Length frequency polygon of S. pseudoheterolobus in 1970-1971. 

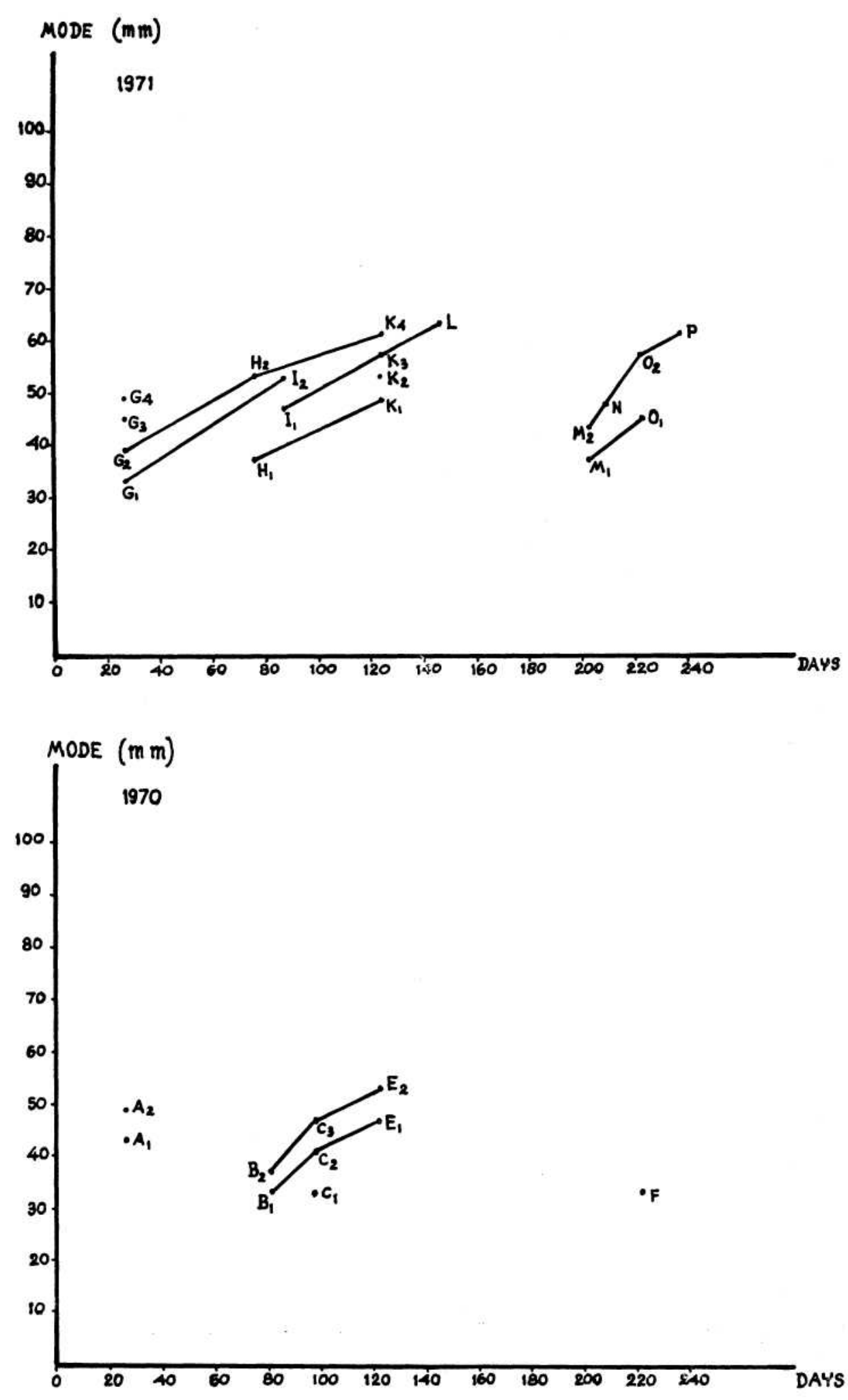

Figure 10.

Mode chains of S. pseudoheterolobus. 


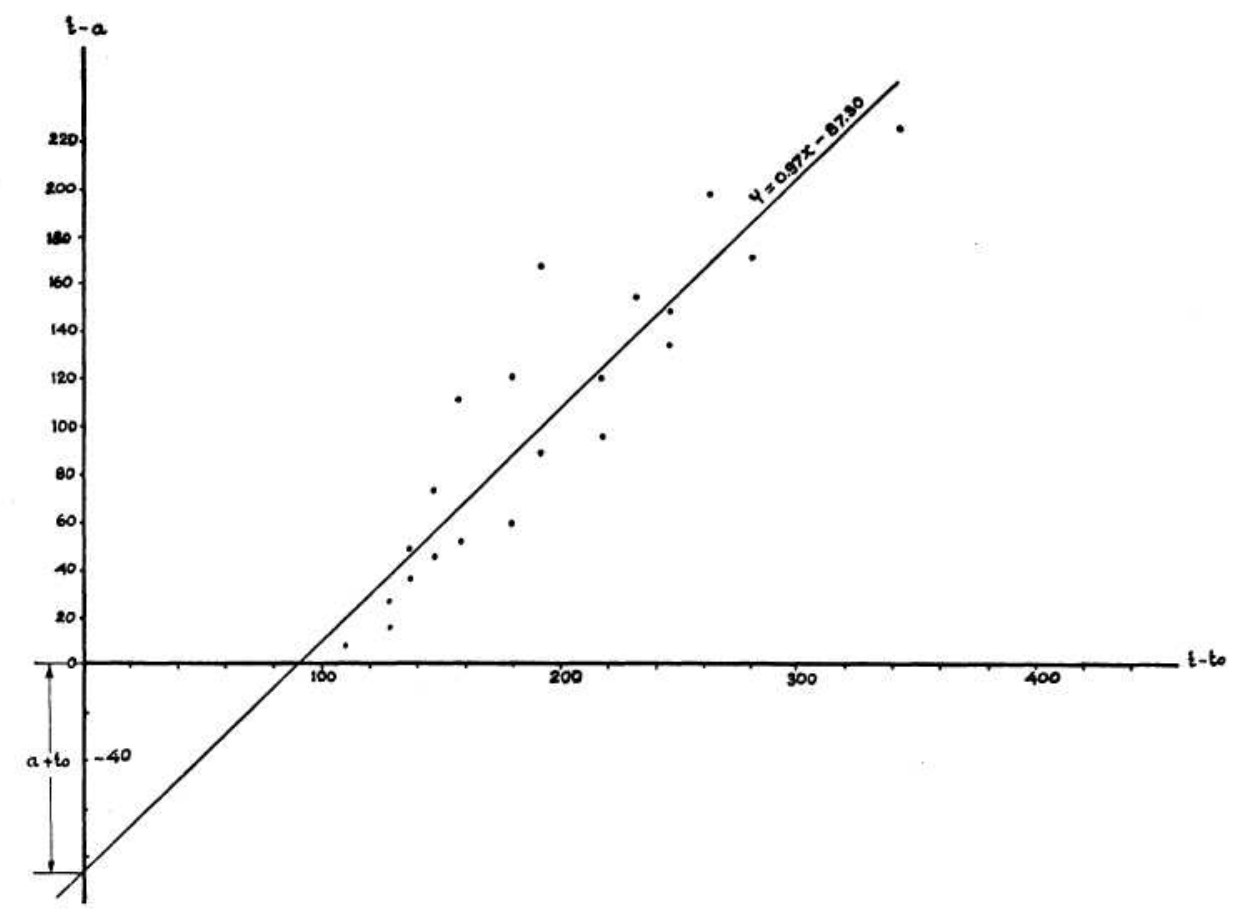

Figure 11.

S. pseudoheterolobus Regression of $(t-a)$ on $\left(t-t_{0}\right)$

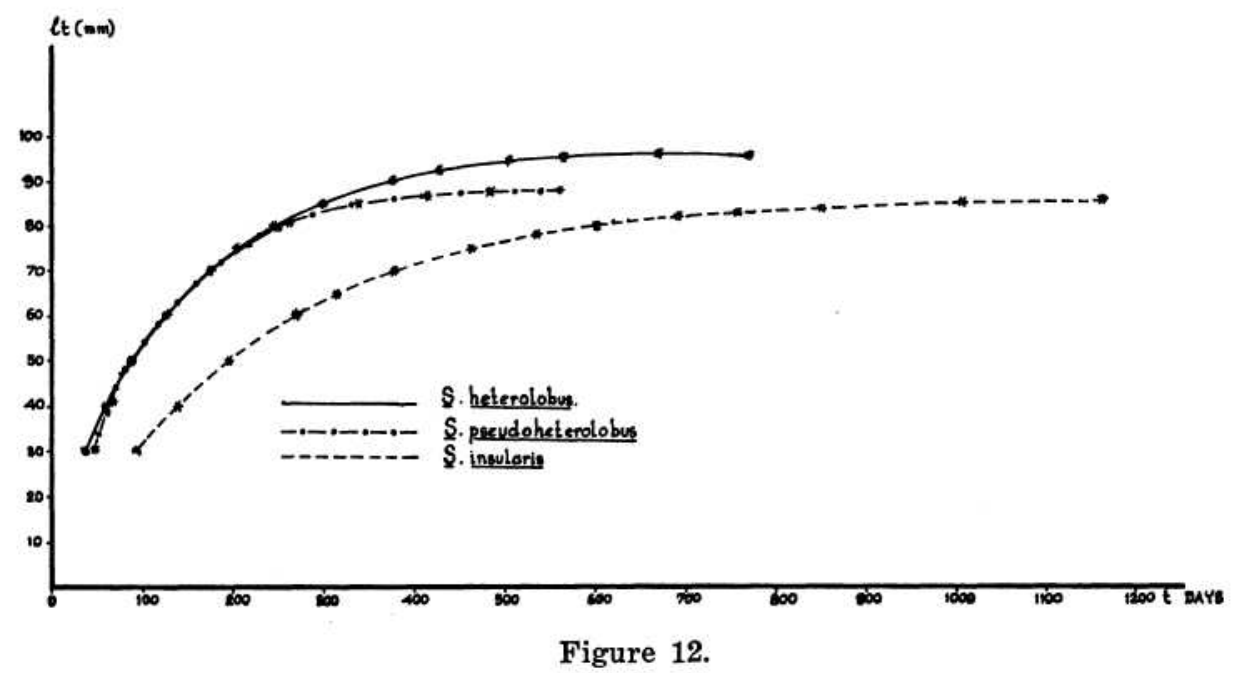

Growth curve of S. heterolobus, S. pseudoheterolobus and S. insularis. 

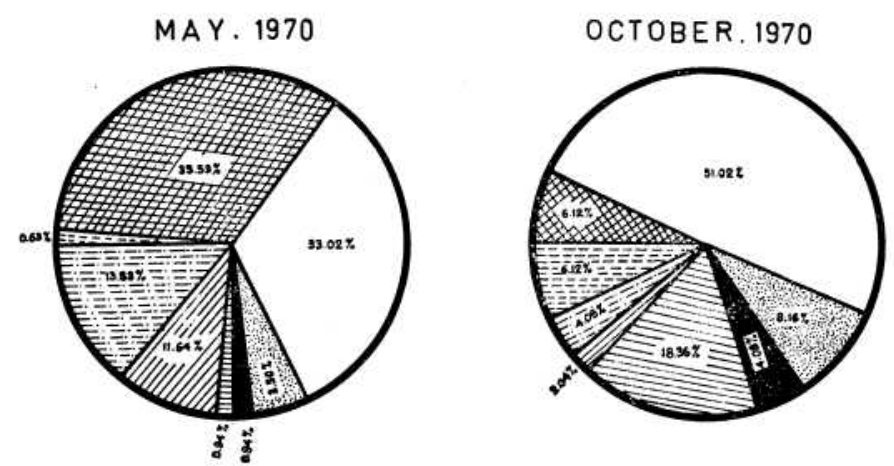

JUNE. 1970

NOVEMBE R.1970
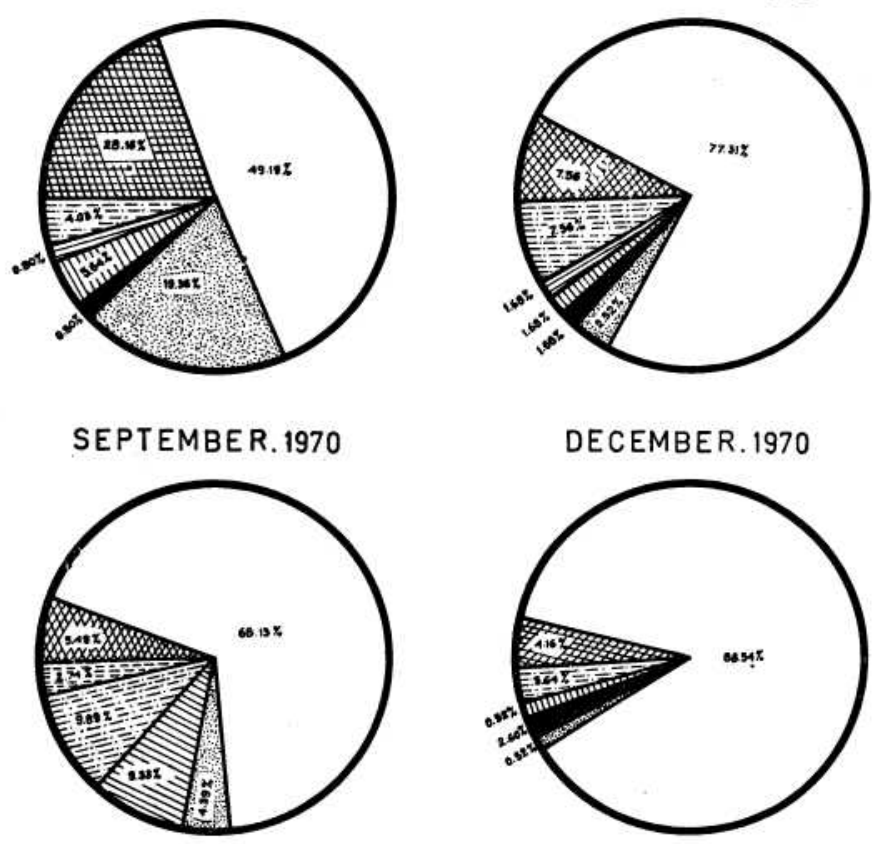

DECEMBER. 1970

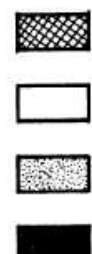

copepod

[IIIIIIII molluse

fragment of erustacea

eggs and fish seale

other crustacea

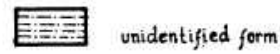

miscellaneous

垔琵 phytoplankton

Figure 13.

Seasonal variations of the percentage composition of food items in the diet of S. heterolobus in 1970. 

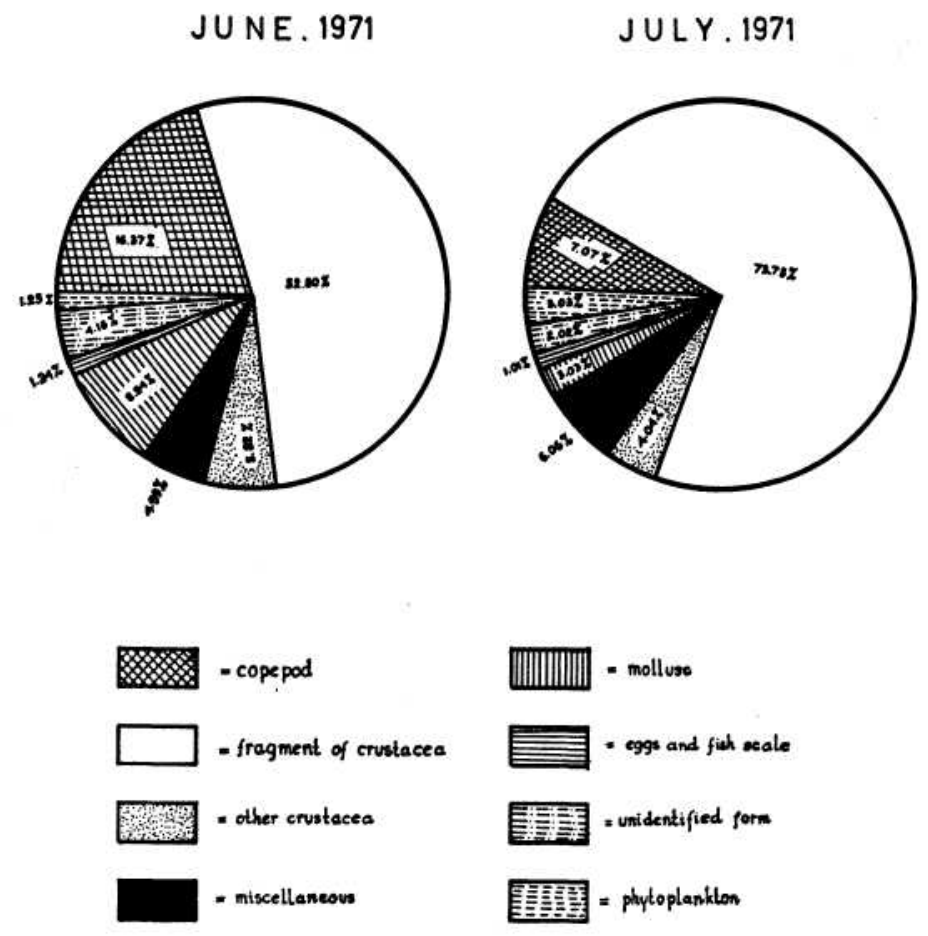

- copepod

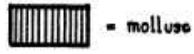

- fragment of crustacea

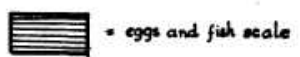

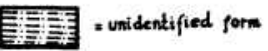

- miscellanear

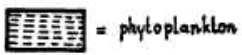

Figure 14.

The percentage composition of food items in the diet of S. heterolobus in 1971. 

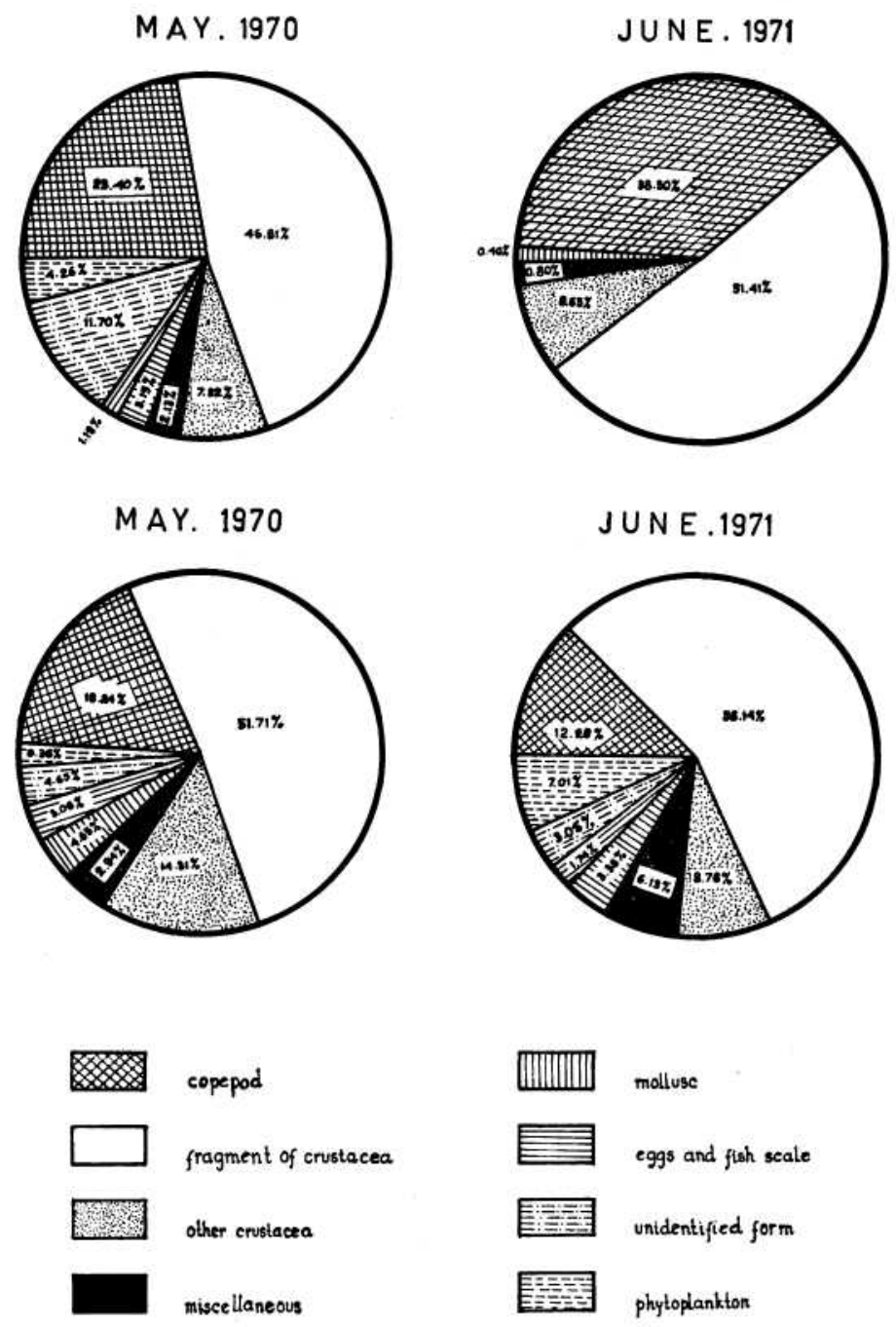

Figure 15.

The percentage composition of food items in the diet of $S$. pseudoheterolobus in 1970 and 1971. 
Table I

Instantaneous growth rates and mean lengths of Stolephorus heterolobus.

\begin{tabular}{|c|c|c|c|c|c|c|c|}
\hline \multirow{2}{*}{ Modes } & \multirow{2}{*}{$1_{2}(\mathrm{~mm})$} & \multirow{2}{*}{ Modes } & \multirow{2}{*}{$1_{1}(\mathrm{~mm})$} & \multicolumn{2}{|c|}{ Date } & \multirow{2}{*}{$\frac{1_{2}-1_{1}}{t_{2}-t_{1}}$} & \multirow{2}{*}{$\frac{1_{2}+1_{1}}{2}$} \\
\hline & & & & $t_{2}$ & $t_{1}$ & & \\
\hline $21 / N$ & 43 & $17 / M_{1}$ & 37 & $28 / 5-70$ & $13 / 5.70$ & 0.4000 & 40 \\
\hline $11 / P_{8}$ & 53 & $21 / \mathrm{N}$ & 43 & $15 / 6-70$ & $28 / 5-70$ & 0.5555 & 48 \\
\hline $14 / P_{2}$ & 45 & $22 / 0$ & 39 & $15 / 6-70$ & $6 / 6-70$ & 0.6666 & 42 \\
\hline $20 / Q_{2}$ & 53 & $14 / \mathrm{P}_{2}$ & 45 & $11 / 7-70$ & $15 / 6-70$ & 0.3076 & 49 \\
\hline $7 / Q_{1}$ & 47 & $6 / P_{1}$ & 39 & $11 / 7-70$ & $15 / 6-70$ & 0.3076 & 43 \\
\hline $9 / \mathrm{S}_{3}$ & 49 & $18 / R_{2}$ & 43 & $24 / 9-70$ & $10 / 9-70$ & 0.4285 & 46 \\
\hline $13 / \mathrm{S}_{2}$ & 43 & $9 / R_{1}$ & 35 & $24 / 9-70$ & $10 / 9-70$ & 0.5714 & 39 \\
\hline $19 / V_{2}$ & 59 & $9 / \mathrm{S}_{3}$ & 49 & $10 / 11-70$ & $24 / 9-70$ & 0.2127 & 54 \\
\hline $15 / V_{1}$ & 55 & $13 / \mathrm{S}_{2}$ & 43 & $10 / 11-70$ & $24 / 9-70$ & 0.2553 & 49 \\
\hline $15 / T_{2}$ & 41 & $10 / \mathrm{S}_{1}$ & 35 & $20 / 10-70$ & $24 / 9-70$ & 0.2307 & 38 \\
\hline $12 / \mathrm{W}_{1}$ & 49 & $15 / \mathrm{T}_{2}$ & 41 & $24 / 11-70$ & $20 / 10-70$ & 0.2285 & 45 \\
\hline $14 / W_{3}$ & 59 & $15 / V_{1}$ & 55 & $24 / 11-70$ & $10 / 11-70$ & 0.2857 & 57 \\
\hline $22 / X$ & 39 & $27 / U$ & 33 & $19 / 12-70$ & $23 / 10-70$ & 0.1052 & 36 \\
\hline $18 / B$ & 53 & $15 / A_{2}$ & 45 & $24 / 2-71$ & $13 / 2-71$ & 0.7272 & 49 \\
\hline $9 / C_{2}$ & 57 & $10 / A_{1}$ & 37 & $7 / 5-71$ & $13 / 2-71$ & 0.2352 & 47 \\
\hline $15 / E_{s}$ & 57 & $15 / D_{3}$ & 55 & $16 / 5-71$ & $8 / 5-71$ & 0.2500 & 56 \\
\hline $8 / E_{1}$ & 47 & $14 / \mathrm{C}_{1}$ & 41 & $16 / 5-71$ & $7 / 5-71$ & 0.6666 & 44 \\
\hline $13 / G_{3}$ & 55 & $8 / E_{1}$ & 47 & $19 / 6-71$ & $16 / 5-71$ & 0.2352 & 51 \\
\hline $21 / \mathrm{H}_{3}$ & 57 & $5 / D_{1}$ & 37 & $12 / 7-71$ & $8 / 5-71$ & 0.3076 & 47 \\
\hline $8 / G_{2}$ & 41 & $18 / \mathrm{F}$ & 37 & $19 / 6-71$ & $30 / 5-71$ & 0.2000 & 39 \\
\hline $3 / \mathrm{H}_{2}$ & 47 & $8 / \mathrm{G}_{2}$ & 41 & $12 / 7-71$ & $19 / 6-71$ & 0.2608 & 44 \\
\hline $3 / \mathrm{H}_{1}$ & 43 & $13 / G_{1}$ & 33 & $12 / 7-71$ & $19 / 6-71$ & 0.4347 & 38 \\
\hline $26 / K$ & 57 & $3 / \mathrm{H}_{2}$ & 47 & $19 / 9-71$ & $12 / 7-71$ & 0.1449 & 52 \\
\hline $26 / J$ & 55 & $3 / \mathrm{H}_{1}$ & 43 & $12 / 9-71$ & $12 / 7-71$ & 0.1739 & 49 \\
\hline $8 / L_{2}$ & 57 & $26 / J$ & 55 & $29 / 9-71$ & $12 / 9-71$ & 0.1176 & 56 \\
\hline
\end{tabular}


Table II

The value of $t-t_{0}$ for each value of $l_{t}$ of Stolephorus heteralobus.

\begin{tabular}{|c|c|c|c|}
\hline Modes & $1_{t}(\mathrm{~mm})$ & Age: days & $t-t_{0}$ \\
\hline $13 / G_{1}$ & 33 & a & 63 \\
\hline $3 / \mathrm{H}_{1}$ & 43 & $a+23$ & 89 \\
\hline $26 / J$ & 55 & $a+85$ & 127 \\
\hline $8 / \mathrm{L}$ & 57 & $a+102$ & 134 \\
\hline $18 / F$ & 37 & $a+10$ & 73 \\
\hline $8 / \mathrm{G}_{2}$ & 41 & $a+30$ & 83 \\
\hline $3 / \mathrm{H}_{2}$ & 47 & $a+53$ & 100 \\
\hline $26 / K$ & 57 & $a+112$ & 134 \\
\hline $5 / D_{1}$ & 37 & $a+10$ & 73 \\
\hline $21 / \mathrm{H}_{3}$ & 57 & $a+75$ & 134 \\
\hline $14 / C_{1}$ & 41 & $a+20$ & 83 \\
\hline $8 / \mathrm{E}_{1}$ & 47 & $a+29$ & 100 \\
\hline $13 / G_{3}$ & 55 & $a+63$ & 127 \\
\hline $15 / D_{3}$ & 55 & $a+63$ & 127 \\
\hline $15 / E_{3}$ & 57 & $a+71$ & 134 \\
\hline $10 / A_{1}$ & 37 & $a+10$ & 73 \\
\hline $9 / \mathrm{C}_{2}$ & 57 & $a+95$ & 134 \\
\hline 15/A, & 45 & $a+31$ & 94 \\
\hline $18 / B$ & 53 & $a+42$ & 120 \\
\hline $27 / U$ & 33 & $a+0$ & 63 \\
\hline $22 / X$ & 39 & $a+57$ & 78 \\
\hline $10 / \mathrm{S}_{1}$ & 35 & $a+5$ & 68 \\
\hline $15 / T_{2}$ & 41 & $a+31$ & 83 \\
\hline $12 / W_{1}$ & 49 & $a+66$ & 107 \\
\hline $9 / R_{1}$ & 35 & $a+5$ & 68 \\
\hline $13 / \mathrm{S}_{3}$ & 43 & $a+19$ & 89 \\
\hline $15 / V_{1}$ & 55 & $a+66$ & 127 \\
\hline $14 / W_{3}$ & 59 & $a+80$ & 142 \\
\hline $18 / R_{2}$ & 43 & $a+26$ & 89 \\
\hline $9 / \mathrm{S}_{\mathbf{z}}$ & 49 & $a+40$ & 107 \\
\hline $19 / V_{2}$ & 59 & $a+87$ & 142 \\
\hline $6 / P_{1}$ & 39 & $a+15$ & 78 \\
\hline $7 / Q_{1}$ & 47 & $a+41$ & 100 \\
\hline $22 / 0$ & 39 & $a+15$ & 78 \\
\hline $14 / \mathrm{P}_{2}$ & 45 & $a+24$ & 94 \\
\hline $20 / Q_{2}$ & 53 & $a+50$ & 120 \\
\hline $17 / M_{1}$ & 37 & $a+10$ & 73 \\
\hline $21 / N$ & 43 & $a+25$ & 89 \\
\hline $11 / \mathrm{P}_{\mathrm{s}}$ & 53 & $a+43$ & 120 \\
\hline
\end{tabular}


Table III

Instantaneous growth rates and mean lengths of Stolephorus insularis.

\begin{tabular}{|c|c|c|c|c|c|c|c|}
\hline \multirow{2}{*}{ Modes } & \multirow{2}{*}{$1_{2}(\mathrm{~mm})$} & \multirow{2}{*}{ Modes } & \multirow{2}{*}{$1_{1}(\mathrm{~mm})$} & \multicolumn{2}{|c|}{ Date } & \multirow{2}{*}{$\frac{1_{2}-1_{1}}{t_{2}-t_{1}}$} & \multirow{2}{*}{$\frac{1,+1}{2}$} \\
\hline & & & & t, & $t_{1}$ & & \\
\hline $13 / C_{1}$ & 37 & $11 / B_{1}$ & 31 & $28 / 5-70$ & $13 / 5-70$ & 0.4000 & 34 \\
\hline $10 / \mathrm{D}_{\mathrm{z}}$ & 47 & $13 / \mathrm{C}_{1}$ & 37 & $11 / 7-70$ & $28 / 5-70$ & 0.2272 & 42 \\
\hline $36 / \mathrm{E}$ & 53 & $10 / D_{2}$ & 47 & $10 / 9-70$ & $11 / 7-70$ & 0.0983 & 50 \\
\hline $13 / F_{3}$ & 57 & $36 / E$ & 53 & $24 / 9-70$ & $10 / 9-70$ & 0.2857 & 55 \\
\hline $3 / F_{2}$ & 47 & $23 / D_{1}$ & 41 & $24 / 9-70$ & $11 / 7-70$ & 0.0800 & 44 \\
\hline $2 / \mathrm{G}_{2}$ & 49 & $3 / F_{2}$ & 47 & $10 / 11-70$ & $24 / 9-70$ & 0.0425 & 48 \\
\hline $16 / \mathrm{C}_{2}$ & 43 & $25 / B_{2}$ & 39 & $28 / 5-70$ & $13 / 5-70$ & 0.2666 & 41 \\
\hline $10 / \mathrm{D}_{3}$ & 53 & $16 / \mathrm{C}_{2}$ & 43 & $11 / 7-70$ & $28 / 5-70$ & 0.2272 & 48 \\
\hline $18 / \mathrm{F}$ & 61 & $10 / D_{3}$ & 53 & $24 / 9-70$ & $11 / 7-70$ & 0.1066 & 57 \\
\hline $27 / \mathrm{K}_{1}$ & 43 & $26 / I_{1}$ & 41 & $16 / 5-71$ & $8 / 5-71$ & 0.2500 & 42 \\
\hline $7 / \mathrm{L}_{3}$ & 55 & $27 / \mathrm{K}_{1}$ & 43 & $31 / 7-71$ & $16 / 5-71$ & 0.1578 & 49 \\
\hline $23 / \mathrm{M}$ & 59 & $7 / \mathrm{L}_{3}$ & 55 & $12 / 9-71$ & $31 / 7-71$ & 0.0930 & 57 \\
\hline $12 / \mathrm{N}_{2}$ & 57 & $13 / \mathrm{L}_{2}$ & 49 & $29 / 9-71$ & $31 / 7-71$ & 0.1333 & 53 \\
\hline $33 / \mathrm{R}$ & 67 & $12 / \mathrm{N}_{2}$ & 57 & $13 / 12-71$ & $29 / 9-71$ & 0.1333 & 62 \\
\hline $16 / C_{2}$ & 41 & $13 / L_{1}$ & 33 & $4 / 10-71$ & $31 / 7-71$ & 0.1230 & 37 \\
\hline $22 / \mathrm{P}$ & 39 & $15 / 0_{1}$ & 37 & $26 / 10-71$ & $4 / 10-71$ & 0.0909 & 38 \\
\hline
\end{tabular}


Table IV

The value of $t-t_{0}$ for each value of $l_{t}$ of Stolephorus insularis.

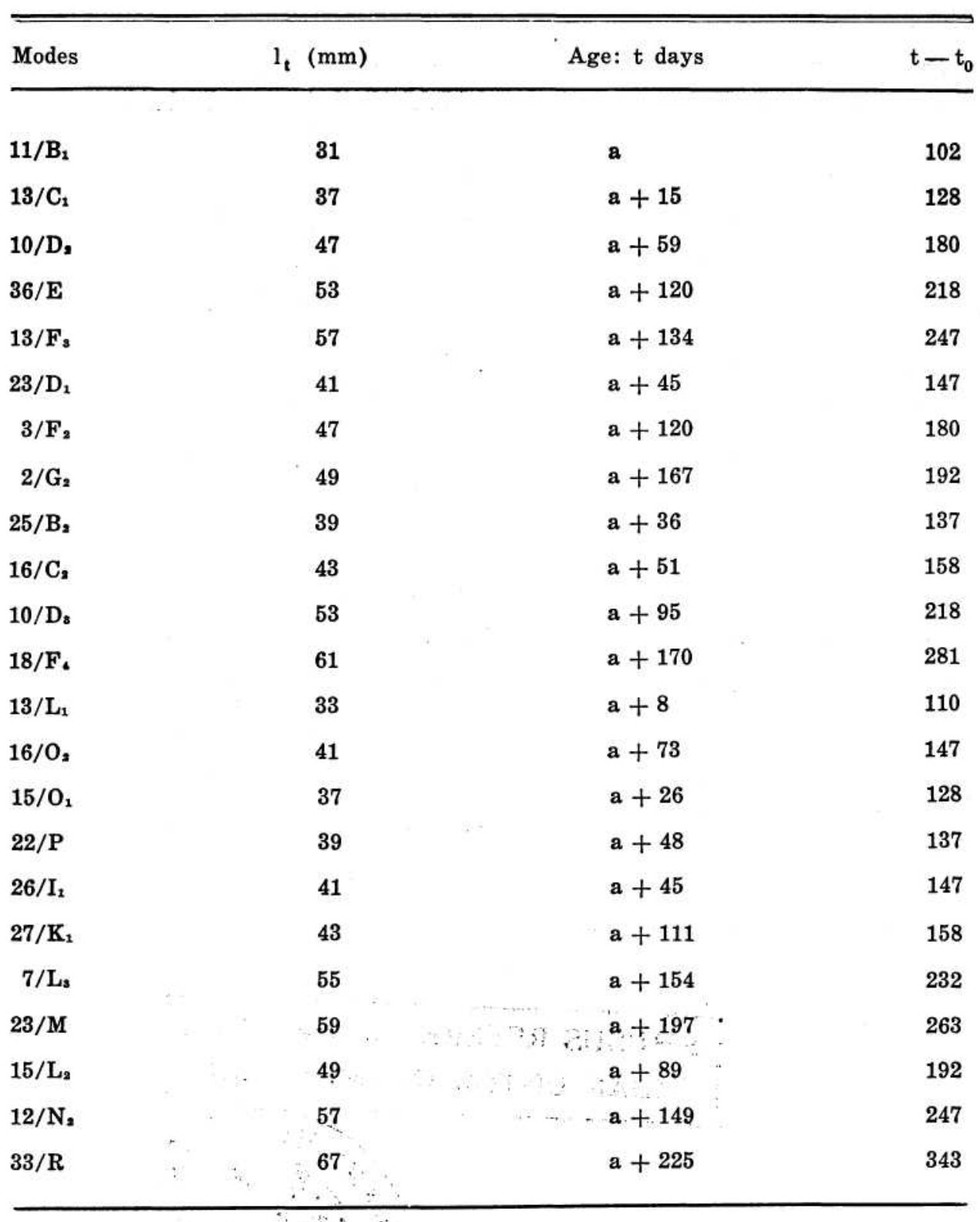


Table V

Instantaneous growth rates and mean lengths of Stolephorus pseudoheterolobus.

\begin{tabular}{|c|c|c|c|c|c|c|c|}
\hline \multirow{2}{*}{ Modes } & \multirow{2}{*}{$1_{2}(\mathrm{~mm})$} & \multirow{2}{*}{ Modes } & \multirow{2}{*}{$1_{1}(\mathrm{~mm})$} & \multicolumn{2}{|c|}{ Date } & \multirow{2}{*}{$\frac{1_{2}-1_{1}}{t_{2}-t_{1}}$} & \multirow{2}{*}{$\frac{1_{2}+1_{1}}{2}$} \\
\hline & & & & $t_{2}$ & $t_{1}$ & & \\
\hline $15 / \mathrm{C}_{2}$ & 41 & $25 / B_{1}$ & 33 & $6 / 6-70$ & $20 / 5-70$ & 0.4705 & 37 \\
\hline $13 / \mathrm{E}$ & 47 & $15 / C_{2}$ & 41 & $30 / 6-70$ & $6 / 6-70$ & 0.2500 & 44 \\
\hline $10 / \mathrm{C}_{3}$ & 47 & $22 / \mathrm{B}_{2}$ & 37 & $6 / 6-70$ & $20 / 5-70$ & 0.5882 & 42 \\
\hline $17 / \mathrm{E}_{2}$ & 53 & $10 / \mathrm{C}_{3}$ & 47 & $30 / 6-70$ & $6 / 6-70$ & 0.2500 & 30 \\
\hline $20 / \mathrm{H}_{2}$ & 53 & $11 / \mathrm{C}_{2}$ & 39 & $15 / 6-71$ & $27 / 4-71$ & 0.2857 & 46 \\
\hline $36 / \mathrm{K}_{4}$ & 61 & $20 / \mathrm{H}_{2}$ & 53 & $31 / 7-71$ & $15 / 6-71$ & 0.1739 & 57 \\
\hline $14 / \mathrm{I}_{2}$ & 53 & $8 / \mathrm{C}_{1}$ & 33 & $27 / 6-71$ & $27 / 4-71$ & 0.3278 & 43 \\
\hline $15 / \mathrm{K}_{3}$ & 57 & $17 / \mathrm{I}_{1}$ & 47 & $31 / 7-71$ & $27 / 6-71$ & 0.2941 & 52 \\
\hline $21 / L$ & 63 & $15 / K_{3}$ & 57 & $29 / 8-71$ & $31 / 7-71$ & 0.2068 & 60 \\
\hline $4 / \mathrm{K}_{1}$ & 49 & $6 / \mathrm{H}_{1}$ & 37 & $31 / 7-71$ & $15 / 6-71$ & 0.2608 & 43 \\
\hline $20 / \mathrm{N}$ & 47 & $13 / \mathrm{M}_{2}$ & 43 & $26 / 10-71$ & $20 / 10-71$ & 0.6666 & 45 \\
\hline $8 / \mathrm{O}_{2}$ & 57 & $20 / \mathrm{N}$ & 47 & $9 / 11-71$ & $26 / 10-71$ & 0.7142 & 52 \\
\hline $28 / \mathrm{P}$ & 61 & $8 / \mathrm{O}_{2}$ & 57 & $24 / 11-71$ & $9 / 11-71$ & 0.2666 & 59 \\
\hline $17 / O_{1}$ & 45 & $16 / \mathrm{M}_{1}$ & 37 & $9 / 11-71$ & $20 / 10-71$ & 0.4000 & 41 \\
\hline
\end{tabular}




\section{Table VI}

The value of $t-t_{0}$ for each value of $1_{t}$ of Stolephorus pseudoheterolobus.

\begin{tabular}{|c|c|c|c|c|}
\hline Modes & & $\mathrm{l}_{\mathrm{t}}(\mathrm{mm})$ & Age: $t$ days & $t-t_{0}$ \\
\hline $25 / B_{1}$ & & 33 & a & 51 \\
\hline $15 / C_{2}$ & & 41 & $a+17$ & 68 \\
\hline $13 / \mathrm{E}_{1}$ & & 47 & $a+41$ & 83 \\
\hline $22 / B_{2}$ & & 37 & $a+8$ & 59 \\
\hline $10 / \mathrm{C}_{2}$ & & 47 & $a+25$ & 83 \\
\hline $17 / E_{g}$ & & 53 & $a+49$ & 100 \\
\hline $11 / \mathrm{C}_{2}$ & & 39 & $a+13$ & 64 \\
\hline $20 / \mathrm{H}_{2}$ & & 53 & $a+74$ & 100 \\
\hline $36 / \mathrm{K}$ & & 61 & $a+120$ & 128 \\
\hline $8 / C_{1}$ & & 33 & a & 51 \\
\hline $14 / I_{2}$ & & 53 & $a+61$ & 100 \\
\hline $17 / I_{1}$ & & 47 & $a+32$ & 83 \\
\hline $15 / \mathrm{K}_{3}$ & & 53 & $a+66$ & 113 \\
\hline $21 / L$ & & 63 & $a+95$ & 137 \\
\hline $6 / \mathrm{H}_{1}$ & & 37 & $a+8$ & 59 \\
\hline $34 / \mathrm{K}_{1}$ & & 49 & $a+54$ & 88 \\
\hline $13 / \mathrm{M}_{2}$ & & 43 & $a+22$ & 73 \\
\hline $20 / N$ & & 47 & $a+28$ & 83 \\
\hline $8 / O_{2}$ & & 57 & $a+42$ & 113 \\
\hline $28 / P$ & & 61 & $a+57$ & 128 \\
\hline $16 / M_{1}$ & $\bullet$ & 37 & $a+8$ & 59 \\
\hline $17 / O_{1}$ & . & 45 & $a+28$ & 78 \\
\hline
\end{tabular}


Table VII

The calculated age of three species of Stolephorus at certain length.

\begin{tabular}{|c|c|c|c|}
\hline \multirow{2}{*}{$\begin{array}{l}\text { Standard } \\
\text { Length } \mathrm{mm}\end{array}$} & \multicolumn{3}{|c|}{ Calculated age in days } \\
\hline & S. heterolobus & S. insularis & S. pseudoheterolobus \\
\hline 30 & 32 & 95 & 41 \\
\hline 40 & 57 & 139 & 62 \\
\hline 50 & 86 & 195 & 87 \\
\hline 60 & 122 & 272 & 120 \\
\hline 65 & - & 318 & - \\
\hline 70 & 170 & 379 & 168 \\
\hline 75 & 201 & 464 & 204 \\
\hline 78 & - & 537 & 232 \\
\hline 80 & 240 & 602 & 257 \\
\hline 82 & - & 694 & 281 \\
\hline 83 & - & 760 & - \\
\hline 84 & - & 852 & 332 \\
\hline 85 & 293 & 1,008 & 363 \\
\hline 85.50 & - & 1,164 & - \\
\hline 86 & - & - & 407 \\
\hline 87 & - & - & 482 \\
\hline 87.50 & - & - & 558 \\
\hline 90 & 374 & - & - \\
\hline 92 & 425 & - & - \\
\hline 94 & 503 & - & - \\
\hline 95 & 564 & - & - \\
\hline 96 & 669 & - & - \\
\hline
\end{tabular}




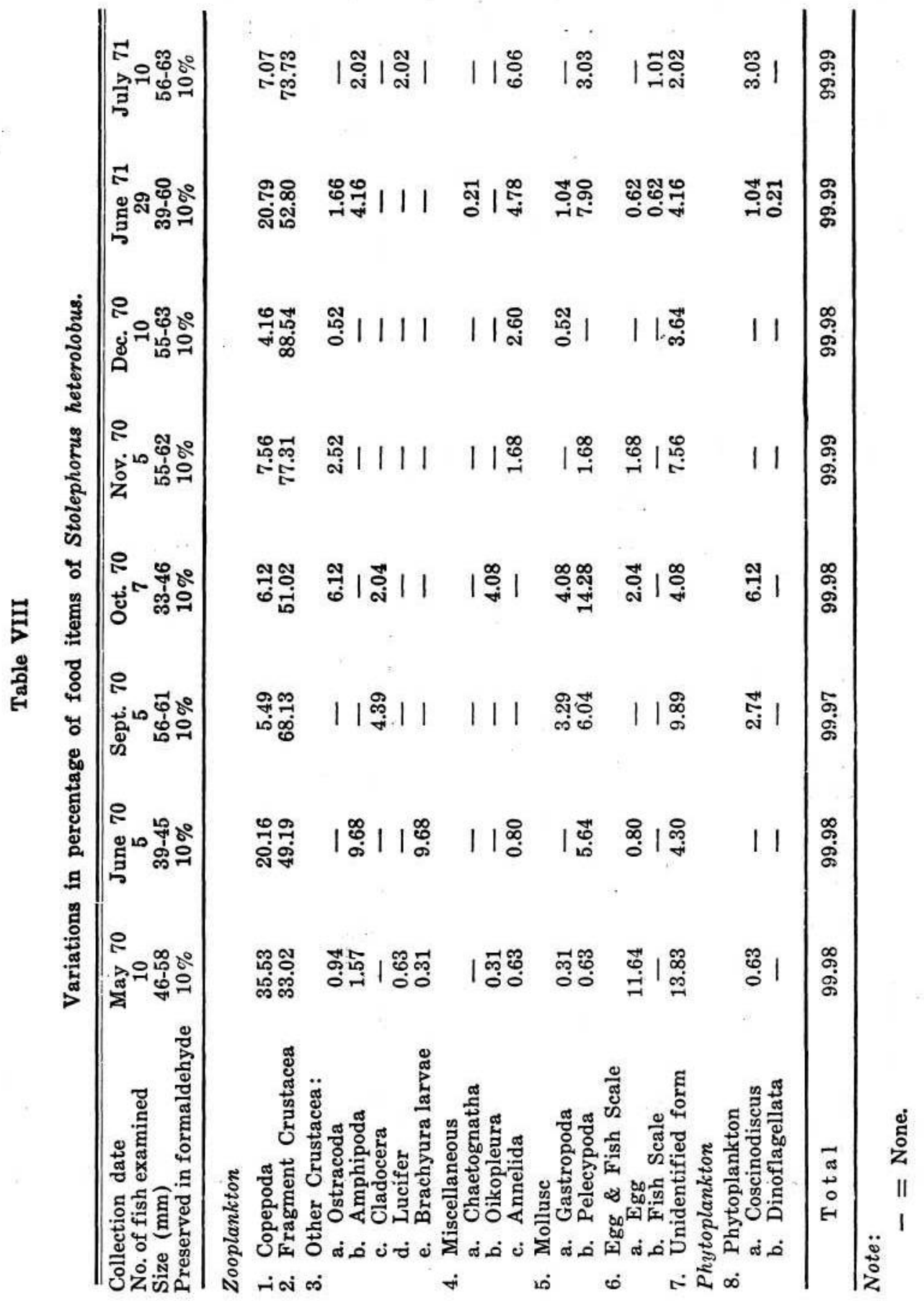

